\title{
Environmental health risks by arsenic consumption in water wells in the Cape region, Mexico
}

\author{
H. Romero-Schmidt, A. Naranjo-Pulido, L. Méndez-Rodríguez, \\ B. Acosta-Vargas \& A. Ortega-Rubio \\ Centro de Investigaciones Biológicas del Noroeste \\ Baja California Sur, México
}

\begin{abstract}
The airn of this work was to evaluate the concentration of arsenic in wells of the San Antonio-El Triunfo region, located in the Baja California Sur (BCS) Mexican State. At this region mineral mining activities flourish during the XIX century. As a byproduct of these activities there were deposited on the soil thousands of tons of debris, which contains high quantities of arsenic. During the summer months of 1997 we developed fieldwork in order to sample these wells. Concentration of arsenic was determined using the Chapman and Parket [1] techniques. The results were statistically analyzed by ANOVA tests. Our results indicates that all the groundwater sampled in the wells of the region exceeds the Mexican official limits $(0.05 \mathrm{mg} / \mathrm{l})$, and that the arsenic quantities in the wells are inversely correlated with the altitude and the $\mathrm{pH}$ of the wells. The implications of such findings to the health risk of the local inhabitants are discussed.
\end{abstract}

\section{Introduction}

Arsenic (As) ranks as the 53rd most natural abundant element [2] it naturally occurring ubiquitously in the biosphere. Arsenic concentrations are variable in natural components of the environment such as soils, sediments, bodies of water, animals and, plants. Its variability depends on proximity and exposure to sources of arsenic whether produced from man or from geological sources [3]. The arsenic contamination of water supplies is known to have been caused by natural geological deposits dissolving [4]; by industrial discharges [3]; by application of pesticides [5]; and as a byproduct of mining activities [6]. Because mining eventually extracts all the profitable resources, mines are abandoned and mining wastes are left on the 
surface of the soil. This is why some of the largest and most complicated deposits of hazardous waste are at mining sites. Mining directly disturbs about $240,000 \mathrm{~km}^{2}$ of the earth's surface [7], an area about the size of state of Oregon.

\section{Sources}

In Mexico, mining has existed more than 400 years and contamination has existed since then, mainly affecting soils, landscapes, and groundwater [8]. It is estimated there are about 10,000 to 50,000 abandoned mines in Mexico [9], and the water contaminated by arsenic has been reported mainly in the Northern Region, between Durango and Coahuila States; and also in Hidalgo; Zacatecas and, Chihuahua, Mexican States. In Baja California Sur, in the San Antonio-El Triunfo mining District in Cape region (Figure 1), there gold and silver have been mined since the XVII century [10] flourish during the XIX century [11] and ended in 1940. As a byproduct of these mining activities there were accumulated approximately 800,000 tons of debris in the region [12] [6].

Arsenic has been discovered in ground water in several countries in all five continents. The literature shows that the major incidents of arsenic contaminated water were in Taiwan [13], Antofagasta, Chile [14], Mexico [5] and Argentina [15]. Other minor incidents of arsenic poisoning from groundwater, have been reported from Minnesota, USA [16], Millard County, Utah [17], Ontario, Canada [18], Nova Scotia, Canada [19], New Zealand [20], Nakajo, Japan [21], but the worst and most recent calamity of all was in West Bengal, India and Bangladesh [22]. The World Health Organization (WHO) standard for arsenic in drinking water is $0.010 \mathrm{mg} / \mathrm{L}$; the French current standard is $0.015 \mathrm{mg} / \mathrm{L}$, Vietnam, Mexican and US EPA standard is $0.050 \mathrm{mg} / \mathrm{L}$. The US is in the process of lowering that to 0.010 $\mathrm{mg} / \mathrm{L}[4]$.

\section{Study site and methods}

Field work was done in the San Antonio-El Triunfo mining district in the southern part of Baja California Sur, Mexico (Figure 1) $\left(23^{\circ} 48^{\prime}\right.$ to $23^{\circ} 49^{\prime} \mathrm{N} ; 110^{\circ} 06^{\prime}$ to $\left.110^{\circ} 03^{\prime} \mathrm{W}\right)$ and at a control site at El Comitan in the northern part of the Cape

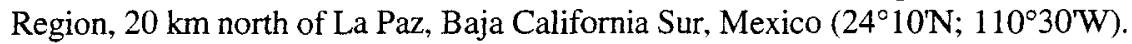

The area of San Antonio-El Triunfo is geologically situated on the central part of the San Lucas tectonic block. Physiographically, it is from sea level to $1000 \mathrm{~m}$ with muddy-sandy soils. The climate is warm-arid with an average annual temperature of $22.1^{\circ} \mathrm{C}$ and maximum precipitation of $156 \mathrm{~mm}$ falling primarily during summer [23]. Its predominant flora is xerophytic scrub [24].

\section{Description of sampling program}

From June to August 1997 we developed three stays of fieldwork, in order to sample all the water wells that provide water to the towns of San Antonio an El Triunfo. Analysis of arsenic was carried out on 27 water samples. Also for each well found we recorded its position using a GPS (Mark X), and its altitude above the sea level. 


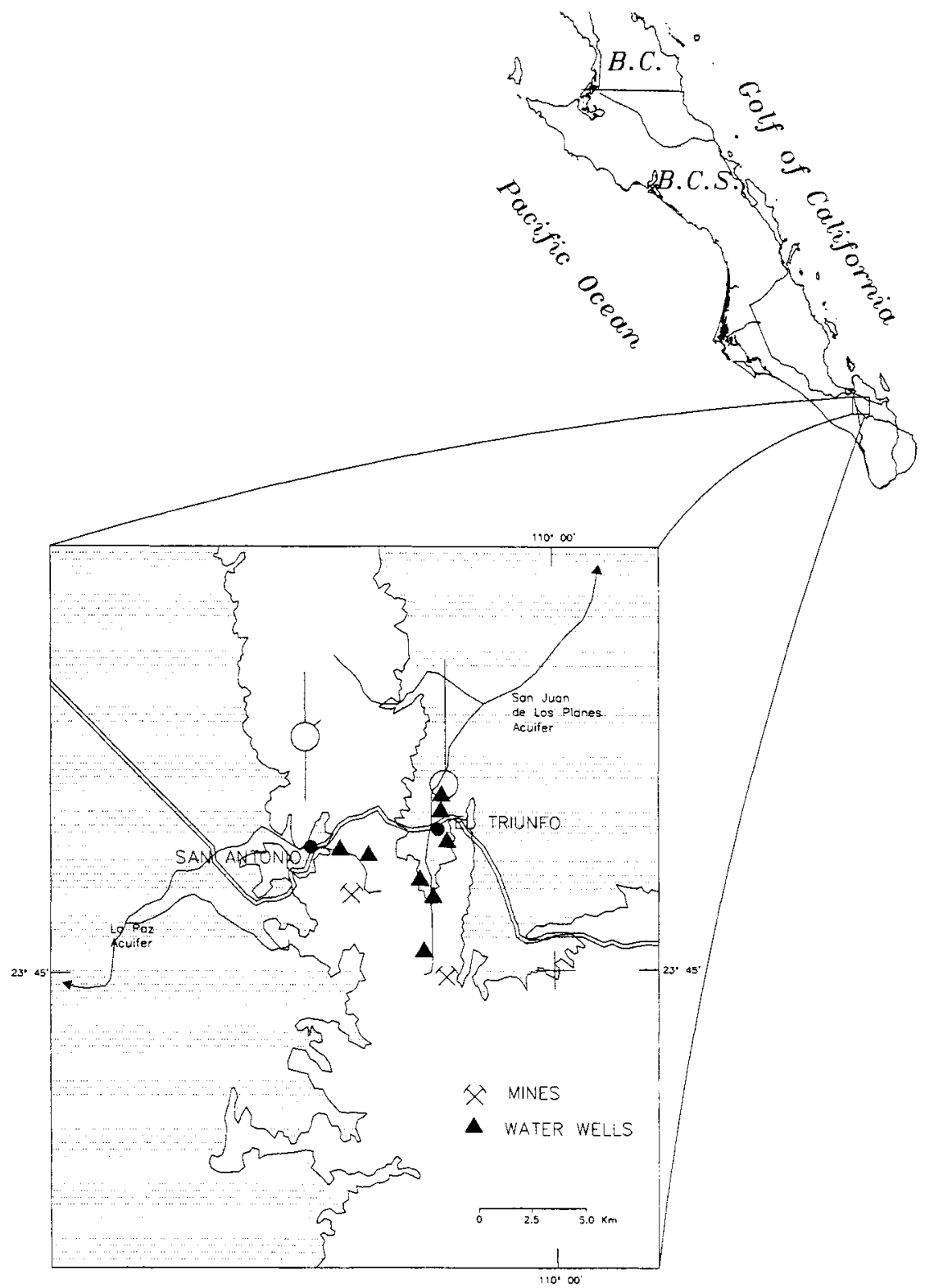

Figure 1: Study Site. Location of the water wells $\sigma$ and mines

All sample equipment was submerged by $24 \mathrm{hrs}$ in nitric acid in order to avoid any possible contamination. Well were sampled using a Vandor bottle and a plastic cord. Three samples were taken for each well. Each sample was the transferred to plastic containers. Water well parameters recorded were: $\mathrm{pH}$ and temperature. In the laboratory water samples were filtered with help of a pump (Vac Model) and 
$47 \mathrm{~mm}$ filters. Samples were then fixed with $\mathrm{pH} \mathrm{2,} \mathrm{nitric} \mathrm{acid} \mathrm{and} \mathrm{Arsenic} \mathrm{was}$ quantified using the standard proceedings [1][25].

Arsenic quantities results were compared by ANOVA test [26] followed by the Tukey-Kramer [26], in order to find statically differences among the samples.

\section{Results and discussion}

Obtained samples (27) were taken from 9 wells. The data on average arsenic concentrations found for each studied well are shown in Table 1. The results indicate that considerable quantities of arsenic are in the samples obtained in San Antonio and El Triunfo. All of them surpass the limits recommended by the WHO $(0.010 \mathrm{mg} / \mathrm{L})$, and almost all above of the Mexican Standards $(0.050 \mathrm{mg} / \mathrm{L})$ except well number 8 and 9 (control site) where the average value was inside the environmental limit (Table 1). There exist differences significative in arsenic concentration among all the wells analyzed $\left\{\mathrm{F}_{(8,18)}=98.06 ; \mathrm{P}<0.0001\right\}$.

Table 1: Arsenic concentrations found in the underground water sampled

\begin{tabular}{|c|c|c|c|c|c|}
\hline $\begin{array}{c}\text { Well } \\
\text { No }\end{array}$ & Town & Location & Altitude & pH & $\begin{array}{c}\text { [As] } \\
(\mathrm{Mg} / \mathrm{l})\end{array}$ \\
\hline & San Antonio & & 400 & - & - \\
\hline 1 & $\begin{array}{c}\text { Los San } \\
\text { Juanes }\end{array}$ & $\begin{array}{c}23^{\circ} 47^{\prime} 47 \mathrm{~N} \\
11^{\circ} 03^{\prime} 20 \mathrm{~W}\end{array}$ & 480 & 6.2 & 0.0871 \\
\hline 2 & 1 Km North & $\begin{array}{c}23^{\circ} 47^{\prime} 14 \mathrm{~N} \\
10^{\circ} 03^{\prime} 20 \mathrm{~W}\end{array}$ & 470 & 6.3 & 0.0903 \\
\hline 3 & 1.9 North & $\begin{array}{c}23^{\circ} 47^{\prime} 11 \mathrm{~N} \\
11^{\circ} 03^{\prime} 27 \mathrm{~W}\end{array}$ & 460 & 6.1 & 0.1904 \\
\hline 4 & 1.95 North & $\begin{array}{c}23^{\circ} 47^{\prime} 11 \mathrm{~N} \\
10^{\circ} 03^{\prime} 20 \mathrm{~W}\end{array}$ & 420 & 6.2 & 0.1754 \\
\hline 5 & 2.85 North & $\begin{array}{c}23^{\circ} 48^{\prime} 50 \mathrm{~N} \\
11^{\circ} 03^{\prime} 10 \mathrm{~W}\end{array}$ & 380 & 6.1 & 0.1676 \\
\hline 6 & 2.95 North & $\begin{array}{c}23^{\circ} 48^{\prime} 51 \mathrm{~N} \\
10^{\circ} 03^{\prime} 10 \mathrm{~W}\end{array}$ & 360 & 5.9 & 0.2440 \\
\hline 7 & $\begin{array}{c}900 \text { m SW } \\
\text { Los Encinos }\end{array}$ & $\begin{array}{c}23^{\circ} 48^{\prime} 02 \mathrm{~N} \\
10^{\circ} 06^{\prime} 22 \mathrm{~W}\end{array}$ & 520 & 7.2 & 0.0942 \\
\hline 8 & 850 SW & $\begin{array}{c}23^{\circ} 48^{\prime} 03 \mathrm{~N} \\
10^{\circ} 06^{\prime} 22 \mathrm{~W}\end{array}$ & 500 & 7.3 & 0.0430 \\
\hline 9 & Comitan & $\begin{array}{c}24^{\circ} 08^{\prime} 10 \mathrm{~N} \\
110^{\circ} 26^{\prime} 30 \mathrm{~W}\end{array}$ & 10 & 7.8 & 0.0000 \\
\hline
\end{tabular}


There are differences between the wells of towns $\left(F_{(2,24)}=17.51 ; P<0.0001\right)$, being San Antonio the town with major arsenic concentration. The tester well (No. 9) no has arsenic detectable by this technique.

In the Table 2 it is possible to observe that groups. The wells number 9 and 8 were significativelly different among of them and from all the others (groups A, $B$ respectively) with low values, under the official standards. Also there are two other groups of wells, well differentiated: Wells numbers 1,2 and 7 are statistically equal among them (group C); wells 3,4 and 5 were in other homogeneous group (D) and exhibits medium values of arsenic concentration; meanwhile the well number 6 (group E) has the major concentration of arsenic.

There exist a statistically significative inverse correlation between the $\mathrm{pH}$ and arsenic concentration in the samples (As $=-0.7577 ; r^{2}=0.5742 ; Y=-0.0968 x$ +0.7572 ). It is to say that a mayor acidity of the water, the quantity of arsenic is higher.

Table 2: Well's homogeneous groups resulting from the Tukey-Kramer statistical analysis $(\mathrm{p}<0.05)$

\begin{tabular}{|c|c|}
\hline Homogeneus Groups & Well No. \\
\hline A & 9 \\
\hline B & 8 \\
\hline C & $1,2,7$ \\
\hline D & $3,4,5$ \\
\hline E & 6 \\
\hline
\end{tabular}

Both at San Antonio and El Triunfo, the arsenic concentration in the wells are inversely correlated with the altitude (Altitude $=-0.8352 ; \mathrm{r}^{2}=0.6976 ; \mathrm{Y}=-0.001 \mathrm{x}$ +0.582 ). It is to say, at the wells located in the lower part there were found higher concentrations of arsenic.

To the beginning of this work it was expected to find a concentration of more arsenic in the wells of water near to the ancient prosecution plants, or debris [9]. However when analyzing the results one observes that the concentration of arsenic increases as it diminishes the slope of the stream where these wells are distributed, independently of the proximity of the waste. This is attributed to the rainfall water percolation that transport through the groundwater the arsenic, and because the slope such groundwater is accumulated in the lower parts.

The concern mainly arises became some people may be tempted to play down the problem. People handle arsenic differently, specially because their effects are shown in the long run, and because people used to mining activities usually does not recognize the gravity of the problem.

\section{Medical aspects of arsenic}

Arsenic poisoning can happen in two ways: acute poisoning results from ingesting a large amount of arsenic in a short time, while ingestion of small amounts of arsenic over long time periods leads to chronic poisoning. 
Arsenic tends not to accumulate in the body, but is excreted through the kidneys. If ingested faster than it can be excreted, arsenic does accumulate in hair and fingernails.

Symptoms of early intoxication involve gastrointestinal problems such as vomiting and lesion to the skin. Chronic intoxication incur skin cancer like blackfoot disease (Guidelines for Drinking-Water Quality [27])

There exist four recognized stages of arsenicosis, or chronic arsenic poisoning:

- Preclinical: the patient shows no symptoms, but arsenic can be detected in urine or body tissue samples.

- Clinical: at this stage various effects can be seen on the skin. General darkening of the skin (melanosis) is the most common symptom, often observed on the palms. Dark spots on the chest, back, limbs, or gums have also been reported. Oedema (swelling of hands and feet) is often seen. A more serious symptom is keratosis, or hardening of skin into nodules, often on palms and soles. WHO estimates that this stage requires five to ten years of exposure to arsenic.

- Complications: clinical symptoms become more pronounced, and internal organs are affected. Enlargement of liver, kidneys, and spleen have been reported. Some research indicates that conjunctivitis (pinkeye), bronchitis and diabetes may be linked to arsenic exposure at this stage.

- Malignancy: tumors or cancers (carcinoma) affect skin or other organs. In this stage the affected person may develop gangrene or skin, lung, or bladder cancer.

In addition to the above clinical signs, arsenic poisoning can cause weakness, loss of appetite, nausea, and diarrhea. In the first two stages or arsenicosis, if the patient switches to an arsenic-free source of water, complete recovery is likely. The third stage may be reversible; the fourth is not.

There is some evidence that providing patients with vitamins (especially vitamin A) and an enriched diet aids in recovery. For this reason, patients are advised to eat plenty of vegetables, especially leafy greens. However, the top priority in treatment is to provide the patient with drinking water free of arsenic.

\section{Toxicity}

\section{Humans and wildlife}

There is not any evidence to prove arsenic is essential to higher ordered organisms. Toxicity depends on the absorbtivity of soluble arsenic in the gastrointestinal system and its rate of removal. Inorganic arsenic is more toxic than organic arsenic [27]. A high percentage of commonly consumed organic compounds are excreted quickly. Consumed inorganic arsenic accummulate in skin, bone, muscle and, hair tissue. Bioassays have been conducted on animals for assessment of arsenic toxicity. From tests, results show that arsenic poisoning causes stroke, reduced cardiac output and, have effects on embryonic development [27]. 


\section{Conclusions}

Due the population density in the towns were the wells are located (aprox. 500 inhabitants), the presence of arsenic in ground water could be not see so important like in other regions of our country, of even for countries like Bangladesh. However, because it is well known that, the slow ingestion of arsenic over a long period of time can cause several forms of cancer like skin, liver, lung, kidney and bladder, as well as other diseases, allowing people to have access to contaminated water is inconceivable [22].

For this reason, we recommend canceling the uses of these wells and to study the effects on the health, up to this date, in the inhabitants of the region.

\section{References}

[1] Chapman H.D. \& Parket F. P., Métodos de análisis para suelos, plantas y aguas. Editorial trillas, México. 195 pp, 1991.

[2] Demayo, A., Guidelines for Surface Water Quality, Inorganic Substances, Arsenic. Inland Waters Directorate. Water Quality Branch. Ottawa. 1979

[3] Parkins G., Environmental Risk Assessment of Spraying Landfill Leachate on The Guelph Turfgrass Institute (GTI) Site. Focus on Lead and Arsenic. Earth and Atmosphere Field Camp, pp. 87-411,1997.

[4] Thanh T. M. \& Om Phan Long., Groundwater Arsenic Contamination: Can It happen in the Mekong Delta? A Vietnamese Perspective. June. Mekongforum Essays. pp.1-6, 1999. http: www.mekongforum.org/long4e.html

[5] Cebrian, M.E., Albores, A., Aguilar, M. \& Blakely, E., Chronic arsenic poisoning in the north of Mexico. Human Toxicology, 2, pp.121-133, 1983.

[6] Carrillo A. \& J.I. Drever., Environmental assessment of potential for arsenic leaching into groundwater from mine wastes in Baja California Sur, Mexico. Geofisica Internacional, 37(1), pp. 35-39, 1998.

[7] Salomons W., Proc. Intl. Hydrology Programme, UNESCO. Asian Inst. Technology, Bangkok, pp. 7-9, 1988.

[8] Ruiz M. J.C., Una propuesta de metodología para la caracterización ambiental de presas de jales. Boletín Técnico del Consejo de Recursos Minerales. SECOFI. VI(32) pp. 2-16, 1999.

[9] Carrillo A. \& H. Huyck., A Genetic model for the Los Uvares gold deposit, Baja Cuifornia Sur, Mexico. Geofísica linternacional 36 (2) pp.111-119, 19c?

[10] Mártinez, A.M., Contenido de arsénico en el agua subterránea de la zona minera de San Antonio, B.C.S., México: Relación con los yacimientos Minerales y Obras Mineras. Tesis de Licenciatura, Departamento de Geología Marina, UABCS, La Paz, B.C.S. 63 pp. 1997.

[11] Jiménez C., Contaminación por Metales Pesados y Metaloides en Baja California Sur y Sus Costas: Revisión Bibliográfica. Area de Ciencias del Mar, UABCS. pp.135, 1994.

[12] González, A., Información general sobre la existencia de jales y terreros 
en el distrito El Triunfo-San Antonio, Consejo de Recursos Minerales, Inédito, 2 pp, 1995.

[13] Lu, F.J., Blackfoot disease : arsenic or humic acid? The Lancet, 336, pp. 115-116, 1990.

[14] Borgono, J.M. \& Greiber, R ,, Epidemiological study of arsenicism in the city of Antofagasta. Trace Substances in Environmental Health, 5. pp.1324, 1971.

[15] Astolfi, E., Maccagno, A., Fernandez, J.C.G., Vaccara, R. \& Stimola, R, Relation between arsenic in drinking water and skin cancer. Biological Trace Element Research. 3, pp.133-143, 1981.

[16] Feinglass, E.J., Arsenic intoxication from well water in the United States. The New England Journal of Medicine, 288 (16) pp.828-830, 1973.

[17] Southwick, J.W., Western, A.E., Beck, M.M., Whitley, T., Isaacs, R., Petajan, J. \& Hansen, C.D., An epidemiological study of arsenic in drinking water in Millard County Utah. Arsenic: Industrial, Biomedical Environmental Perspectives., (eds) Lederer, W.H. and Fensterheim, R.J. Van Nostrand, Reinhold Company, New York, Toronto, London, Melbourne. pp. 210-225,1983.

[18] Wyllie, J., An investigation of the source of arsenic in a well water. Canadian Public Health Journal. 28 pp. 128-135, 1937.

[19] Grantham, D.A. \& Jones, J.F., Arsenic contamination of water wells in Nova Scotia. Journal of American Water Works Association, 69 pp. 653 657, 1977.

[20] Ritchie, J.A., Arsenic and antimony in New Zealand thermal waters. New Zealand Journal of Science, 4 pp. 218-229, 1961.

[21] Terade, H., Katsuta, K., Sasagawa, T., Saito, H., Shirata, H., Fukuchi, K., Sekiya, T., Yokoyama, Y., Hirokawa, S., Watanabe, Y., Hasegawa, K., Oshina, T. \& Sekiguchi, T., Clinical observation of chronic toxicosis by arsenic. Nihon Rinsho, 118, pp. 2394-2403, 1960.

[22] Mizanur Rahman_S. , Arsenic In Bangladesh Ground Water: The World's Greatest Arsenic Calamity. (BCBSNA)-Intronics Technology Center, Dhaka, Bangladesh. February 27-28, Wagner College, New York, USA. 1999.

[23] Arriaga L. \& A. Ortega, La Sierra de La Laguna de Baja California Sur. Pub. 1, CIB. La Paz, B.C.S. pp. 237, 1988.

[24]León, J.L., R. Domínguez, and R. Coria., Aspectos Florísticos.: La Sierra de La Laguna de Baja California Sur. (eds.) Ortega and Arriaga Pub. 1, CIB. La Paz, B.C.S. pp. 83-97,1988.

[25] Demena J., Manual de Procedimientos Analiticos. Buck Scientific, Inc Norwalk, Connecticut. 13 pp, 1992.

[26] Sokal, B.R., \& Rohlf, F.J., Biometry. Freeman Publish Co., San Francisco, 599 pp, 1969.

[27] Committee on Medical and Biologic effects of Environmental Pollutants, Arsenic. National Academy of Sciences, Washington, D.C.,323 pp,1977. 